\title{
A STUDY ON CONTROL PROBLEMS IN ONLINE DISTANCE EDUCATION
}

\author{
Elena Petrosyan ${ }^{1}$ and Vardan Mkrttchian ${ }^{2}$
}

\author{
${ }^{I}$ Yerevan State University, \\ 1 A. Manoogian St, Yerevan 375049, Armenia \\ ${ }^{2}$ All Armenian Internet University, \\ 19a Korjun St, Yerevan 375009, Armenia
}

\begin{abstract}
While the delivery of online instructional courses in higher education institutions is flourishing, students and educators in general recognize the advantages of the new technology. Problems and concerns about online education are touched in various articles and papers but limited researches were conducted to examine in depth the technical and social problems that accompany this new technology. This study examines these problems and concerns regarding online distance education. Hopefully, the information that is provided here will update decision-makers of the current needs and concerns of online students and instructors so that an effective distance-learning program can be fostered in an All Armenian Internet University. Copyright ${ }^{\circledR} 2005$ IFAC
\end{abstract}

Keywords: Distance Education, Online University, Web-based Instruction.

\section{INTRODUCTION}

Because of the rapid development in recent years, the Internet and the World Wide Web is becoming a popular approach for information delivery. As an upcoming technology, it has the potential to strengthen and enhance learning and teaching in higher education (Kljajić, Mkrttchian and Škraba, 2004).

Now many universities and colleges are placing an emphasis on web-based distance education to seek innovative ways to provide flexible course offerings through new media. In fact, the use of Internet to create online learning opportunities for students at a distance has become extremely popular in higher educational institutions. Gubernick and Ebeling (Ellis, 1999) documented this trend towards an expanded role for higher education: “. $.55 \%$ of the U.S.' 2,215 four-year colleges and universities have courses available off-site. Over 1 million students are now plugged into the virtual college classroom, which compares with 13 million attending brick-andmortar schools." There are studies about the student and instructor incentives to go online. These studies reveal a commonality of advantages. The advantages cited most frequently in the literature include: convenience, flexibility increased interaction with instructor, less travel concerns, the ability to reach varied audiences, positive learning experience, single source for course and program materials and increased computer proficiency.

The advantages and benefits of the use of this technology for distance education are obvious and multiple. There are many elaborate discussions in the literature. Hiltz (Hiltz, 1997) regarded online distance delivery not just as a "different" way of doing the same thing but a possible change in the nature and structure of higher education. If such change is about to take place, are there any problems? In fact application of Internet as an instruction media to reach the student at large is not an easy and simple task. There are concerns, barriers, and problems for both students and instructors. In order to fully tap the potential of this new technology, an exploration into these obstacles is of great practical importance. 


\section{THE CONTROL PROBLEMS IN ONLINE DISTANCE EDUCATION}

The ideal of online distance education involves building learning environments that immerse students in the same learning situation across several network locations. To recognize such conceptions, networks should be made transparent to the learning situation. Problems arise whenever technology is not transparent.

\subsection{Digital Divide}

Although the price of computers and concerned peripherals dropped dramatically in the past several years and the use of information technology grew at an incredible rate, digital divide continues to be an issue. According to the report of U.S. Department of Commence, by the time of the survey in September 2001 only $56.5 \%$ of U.S. families have computers and $50.5 \%$ of families have Internet connections. In another study, Valenta et al. (Valenta. Therriault, Dieter and Mrtek, 2001) indicated the cost of equipment, and online phone charges were a problem for some students. Some people simply cannot afford to use them (Mkrttchian and Kljajić, 2004). The finding was echoed in another study, in which Hiltz (Hiltz, 1997) reported $13 \%$ of the students had serious problems in access to a personal computer. In a somewhat more subtle sense, this digital divide also comes into play in web-based distance education. In addition to the need of computers and connectivity, the relevant differences in rates of connection, such as home dial-up, cable modem, digital subscriber line (DSL) service for students may constitute a problem as well. Therefore, accommodations for students with lesser technological resources should be devised (Mkrttchian and Kljajić, 2004).

\section{$2.1 \quad$ Computer Literacy}

While millions of people are embracing these new technologies, many more do not understand them, and distrust them. Bolt and Crawford (Bolt and Crawford, 2000) documented that tens of millions of Americans are not at all conversant with digital tools, and tens of millions more have only a passing familiarity with the most basic of applications such as word processing and email. In addition to the fast development in computer industry, the sophistication and flexibility of software structures for supporting distance education vary extensively.

A student in online distance education setting may come across different software applications, from posting materials on the Web or simple email systems to conferencing systems that have been specially enhanced to support classroom-like experiences, particularly group discussions and joint projects. It can be an overwhelming experience for an off-campus student when his subject area has nothing to do with computers. Although studies show that web-based instruction is helpful in improving students' computer competence, the ultimate purpose of an online course is determined by its own subject area, not predetermined as computer competence (Mkrttchian and Petrosyan, 2004a).

\subsection{More Startup Time}

For both students and faculty, more startup time devoted to solving the "logistics" of Internet delivery seems to be required at the beginning of courses. Yilmaz and Tuzun (Yilmaz and Tuzun, 2001) reported that students indicated that they had to learn new tools and skills such as application software, uploading files, and chat communication. The learning of a new way to communicate can create chaos and frustration at first.

\subsection{Lack of Face-to-Face Contact}

In a web-based distance education environment where students rarely or never see their professors face to face, it is impossible to perceive the professors' facial expression, or detect the voice inflections when a point is being emphasized. This lack of direct communication was addressed in a study conducted by Yilmaz and Tuzun (Yilmaz, and Tuzun, 2001). They reported that instructors engaged in distance education believed that they would be more helpful to their students if they had face-to-face contact with them. This finding was reflected in the study of McKenzie et al (McKenzie, Mims, Bennett, and Waugh, 2000); in which $96.7 \%$ of the faculty felt face-to-face communication would promote students learning. The fact that web-based distance education is short of face-to-face communication leads to some other issues of concern.

In a study with matched subjects, Hiltz (Hiltz, 1997) compared the traditional learning environment with the virtual environment. $\mathrm{He}$ indicated that the majority of students meeting in traditional face-toface courses develop new friendships in class whereas only a third of the online students reported doing so. Although written communication helps in building up friendship, it is obvious that close personal relationships are difficult.

Lack of this direct contact can be a nightmare for some instructors and students. Hailey, Grant-Davie, and Hult (Hailey, Grant-Davie and Hult, 2001) reported a few messages from volatile students unpredictably exploded into flame wars. They believe that if there had been such face-to-face contact the problems could have been avoided.

\section{$2.4 \quad$ Student Isolation}

Having students involved in class discussions is really important for an instructor to grasp an idea about student improvement, student learning, and student problems. But in the online environment, 
students prefer to study alone. It becomes difficult to get students involved in class discussions. Yilmaz and Tuzun (Yilmaz and Tuzun, 2001) reported that even when there was a mechanism for online students to have some discussions they did not respond to each other a lot.

They put up their work on the web when required, but other than that they seldom made any comments about each other's work. Students in this environment also felt it was difficult to get help when problems arose.

\subsection{Communication}

There are different kinds of communication problems in an online environment. Both computersupported collaborative leaning and distance learning encourage a view of technology in which the learning communication is computer-mediated. In this model of communication, technology broadly mediates discourse. Although it allows for some powerful and novel forms of communication, it also runs the risk of eliminating much of what makes informal classroom activity valuable. Leasure, Davis and Thievon (Leasure, Davis and Thievon, 2000) pointed out that asynchronous web-based communication was time consuming and frustrating.

A student often starts with a question that is too general for the instructor to respond. Therefore guidelines on how to frame questions are included as part of the curriculum. Students were asked to refer to a page or objective. Besides, class discussion can be another problem in the online environment. Asynchronous discussions may end up with students uninterested in making comments on others' ideas, while in synchronous setting, as in live chat, responding messages to a particular topic can be out of sequence and create chaos in the chat room. There are also problems in communication among students when it comes to group project (Mkrttchian and Petrosyan, 2004b).

This communication problem between students and instructors could lead to some students forming inappropriate collaboration and taking improper measures against the instructor. Instead of working out their problems, complaints or frustrations with each other or with the instructor, students in such a situation may, in a few passionate minutes, send off copies of a complaint up and down the entire university hierarchy, emailing advisors, department chair, college deans, provosts and university president, local newspapers, and even state politicians.

\subsection{High Dropout and Incomplete Outcomes}

Hiltz (Hiltz, 1997) conducted a research study based on the web-based online instruction at New Jersey Institute of Technology. NJIT had been delivering college courses using an asynchronous learning network system for a decade before this research.
Two complete undergraduate degree programs were already in place through a mix of video plus Internet delivery: Virtual Classroom ${ }^{\mathrm{TM}}$. Virtual Classroom ${ }^{\mathrm{TM}}$ is a computer conferencing system with some software structures to support collaborative learning, including structures to order the transcript of discussions, to enforce active participation, to allocate unique assignment topics, and an electronic grade book. Participation is asynchronous and available from any location through the Internet. This study indicates that dropout or incomplete outcomes are "somewhat more prevalent", although grade distributions for those who complete tend to be similar to those for traditional courses. One needs to note that this study is particular, in that both traditional on campus students and offsite distance students participated in the same online conferences and activities, which in fact not only motivated the discussion, but also extended the influence of an instructor (Mkrttchian and Yelchyan, 2004a).

\subsection{Lack of Technical Support}

System failures and computer glitches are legitimate concerns in an online environment. Lack of technical support is experienced both by instructors and students. For an instructor, the problem can arise from the use of software or a particular hardware. The sophistication and variation of multimedia and online delivery are such that it is unrealistic and unreasonable to require an instructor to be fully knowledgeable of the software chosen for the virtual environment. He is an expert in his subject area, not in the field of information and communication technologies (Mkrttchian and Yelchyan, 2004b). Under this circumstance, seeking technical support can be more time consuming than any other thing in preparation for a course. Students may experience a relatively focused need of such support, but it is by no means trivial for an off-campus student. One of the problems Hiltz (Hiltz, 1997) presented is network connection.

He indicated that $40 \%$ to $50 \%$ of students at NJIT had access problems with busy signals when they tried to dial in. One solution offered was telling all students that they needed to learn how to direct dial and quickly upload and download materials; another solution given was to use ISP access. This results in either the addition of extra computer literacy workload or the increase of access cost to the learning environment.

\subsection{Faculty Time Commitment}

Time commitment from faculty is necessarily increased in the development stage when the traditional course is transformed into an online course. Many people noticed the increase of workload at the development stage of a course preparation. McKenzie et al. (McKenzie, Mims, Bennett and Waugh, 2000) indicated $76 \%$ of online instructors felt they spent more time preparing and 
delivering WebCT courses compared to traditional face-to-face courses.

Their study also showed the need of 4 to 6 hours for course preparation. When an online course is prepared, it needs to be reengineered after a little while. Time investment is again required for the maintenance and continual updating of an existing course. Besides, in a virtual classroom, there is additional administrative work involved in organizing a class for the instructor. One likely issue is homework assignment or projects can be submitted through email, regular mail or in person. The completed homework arrived at different times and days. An instructor must organize them before starting to grade. To provide feedback in an online environment is another area that needs a lot of time and effort. Since students ask their questions basically by sending emails, an instructor can receive a lot of emails related to students' questions and problems. To help students, a prompt reply is expected from the instructor. Failure to do so may produce a negative effect on the side of the students or even to set back their study. McKenzie et al (McKenzie, Mims, Bennett and Waugh, 2000) revealed over half of the faculty spent 1 to 3 hours each week with students online in WebCT.

\subsection{Pedagogical and Instructional Research}

Most of the online instructors come from the traditional face-to-face classroom environment without any additional pedagogical training. What is the difference between online mode and traditional mode?

What is the most effective method for an instructor to deliver a class over the Internet? Questions of this nature should be explored before an instructor goes into a virtual classroom to teach. In some ways, the need for careful instructional design is greater in web-based courses.

\section{$2.10 \quad$ Intellectual Property}

There are ongoing issues related to intellectual property: who owns the rights to the materials created for the online class by a professor? Intellectual ownership issues related to material ranging from journal articles to faculty member's course notes created barricades for remote users wanting online digital access to information and educational resources.

\subsection{Logistical Support}

There are concerns over logistical support to online distance education. Hiltz (Hiltz, 1997) reported in a study that $52 \%$ of virtual students felt that it was easier to fall behind in online classes due to the ease of postponing or procrastinating.

Other issues of the same nature include whether and how faculty should be compensated for their work in preparing course materials for distance delivery, and how to provide adequate support to faculty to master the new skills and techniques they need to be effective in an online environment. Among the many suggestions gathered from the faculty are to give faculty release time to design and deliver online classes, to provide more incentives for online instructors, to limit the enrollments in online courses, and not to force faculty to teach online courses in they do not wish to do so.

\subsection{Social Impact}

There are some other issues that are closely related to the nature of online distance education. These include what is the measurement of being successful in education. Humans are social beings. Social interaction is needed.

\section{CONCLUSIONS}

- The unprecedented development of personal computers and Internet technology was lead to the growth of online distance education. Because of the unique features of web-based courses, it is becoming part of the education delivery method as a supplement for the traditional education mode.

- The trend of putting courses online will continue to attract more institutions to join the effort of distance education. Nevertheless, concerns and problems, (some of which are becoming less prominent, as a result of technology advancement), need to be addressed so that it is utilized effectively for educational purposes. This includes a cooperative effort from all technical, administrative, and educational professionals.

- Technical support is needed to guarantee the communication channel of instruction is effective. Administrative and logistical support is needed to provide incentive and regulatory measures. Instructional and pedagogical researches on the other hand are a constant process to find an appropriate, socially acceptable, and most effective pedagogy for the online distance education.

\section{REFERENCES}

Bolt, D, and R. Crawford, (2000). Digital Divide. New York, NY: TV Books.

Ellis, T. J. (1999). Translating a college course for delivery over the World Wide Web. In: Journal of Instruction Delivery System, 13(3), 14-18.

Hailey, D. E. Jr., K. Grant-Davie, and C. A. Hult, (2001). Online education horror stories worthy of Halloween: A short list of problems and solutions in online instruction. In: Computers and Composition, 18, 387-397.

Hiltz, S. R. (1997). Impacts of college-level courses via asynchronous learning networks: some preliminary results. In: Journal of Asynchronous 
Learning Networks, 1(2), 1-19. March 6, 2003

from

http://www.aln.org/publications/jaln/v1n2/v1n2 hilt.asp

Kljajić, M., V. Mkrttchian and A. Škraba, (2004). Collaborative Learning and Organizational Concept in Virtual University Education, Proc. of the International Conference of Cognition and Exploratory Learning of Digital Age, 396 399. ISBN: 972-98947-7-9.

Leasure, A. R., L. Davis, and S. L. Thievon, (2000). Comparison of student outcomes and preferences in a traditional vs. World Wide Web-based baccalaureate nursing research course. In: Journal of Nursing Education, 39(4), 149-54.

McKenzie, B. K., N. Mims, E Bennett and M. Waugh, (2000). Needs, concerns and practices of online instructors. In: Online Journal of Distance Learning Administration, 3(3). March 12, 2002, from http://www.westga.edu/ distance/ojdla/fall33/m ckenzie33.html

Mkrttchian, V. and M. Kljajić (2004), Study Problems of E-Learning and Virtual Enterprises in Online University, Proc. of the $6^{\text {th }}$ International Conference on Systems Research, Informatics and Cybernetics. 49-53. ISBN: 1894613-62-7.

Mkrttchian, V. and E. Petrosyan (2004a). Multiversion Web Servers of Cooperative Work in All Armenian University Network, Proc. of International Conference Advanced Information Technology in Education. 34-38.

Mkrttchian, V. and E. Petrosyan (2004b), Creation of the Web Servers of Joint Work in All Armenian Internet University Network, Proc. of Internet Conference the Information Technology in Science and Education. 41-44.

Mkrttchian, V. and R. Yelchyan (2004a). Using the Virtual Networking Teaching Laboratory in All Armenian Internet University, Proc. of International Conference Advanced Information Technology in Education. 56-60.

Mkrttchian, V. and R. Yelchyan (2004b), Apply to Virtual Networking Teaching Laboratory in All Armenian Internet University, Proc. of the $4^{\text {th }}$ International Scientific Conference on Internet in Education and Science. 80-83.

Valenta, A., D. Therriault, M. Dieter, and R. Mrtek, (2001). Identifying student attitudes and learning styles in distance education. In: Journal of Asynchronous Learning Networks, 5(2), 111-113. Retrieved Feburary 27, 2003 from

http://www.aln.org/publications/jaln/v5n2/v5n2 valenta.asp

Yilmaz, O., and H. Tuzun, (2001). Web-based instruction: Instructor and student problems. Paper presented at AECT International Conference, Atlanta, GA. 